\title{
The Effect of Anticonvulsant Drugs on GABA-Stimulated Chloride Uptake
}

\author{
J. Francis, S.J. Mihic, W.B. Sneddon and W.M. Burnham
}

\begin{abstract}
Eight anticonvulsant drugs - including clonazepam, diazepam and phenobarbital - were tested for their effects on GABA-stimulated chloride uptake in rat cerebral cortical microsacs (unfiltered synaptoneurosomes). "Mid" and "high" therapeutic concentrations were screened, and, if significant enhancement was found, full concentration-response tests were done. In the initial screens, enhancement of GABA-stimulated uptake was found only with phenobarbital, clonazepam and diazepam. In subsequent concentration-response tests, the effects of phenobarbital were found to occur throughout the range of normal, anticonvulsant concentrations, whereas the effects of clonazepam and diazepam were observed only above the concentrations normally used for the chronic control of seizures or anxiety. These data suggest that phenobarbital's anticonvulsant effects are mediated via the $\mathrm{GABA}_{\mathrm{A}}$ receptor complex, but that the low-dose effects of the benzodiazepines may be mediated via some other mechanism.
\end{abstract}

\begin{abstract}
Résumé: Effets des anticonvulsivants sur la capture de chlorure stimulée par la GABA. Nous avons étudié huit anticonvulsivants - dont le clonazépam, le diazépam et le phénobarbital - pour évaluer leurs effets sur la capture de chlorure stimulée par le GABA dans les microsacs corticaux du cerveau de rat (synaptoneurosomes non filtrés). Les concentrations thérapeutiques "moyennes" et "élevées" ont été identifiées et, lorsqu'un rehaussement significatif était présent, des épreuves de réponse à dose maximum étaient effectuées. Aux premières épreuves, le rehaussement de la capture stimulé par le GABA était observé seulement avec le phénobarbital, le clonazépam et le diazépam. Lors d'épreuves à doses croissantes, nous avons observé que les effets du phénobarbital survenaient sur toute la plage de concentrations anticonvulsivantes normales, alors que les effets du clonazépam et du diazépam ont été observés seulement au-dessus des concentrations utilisées normalement dans le contrôle chronique des crises d'épilepsie ou de l'anxiété. Ces observations suggèrent que la médiation des effets anticonvulsivants du phénobarbital se fait via le complexe du récepteur $\mathrm{GABA}_{\mathrm{A}}$, mais que la médiation des effets de faibles doses de benzodiazépines peut se faire via un autre mécanisme.
\end{abstract}

Can. J. Neurol. Sci. 1994; $21: 3-8$

Gamma-aminobutyric acid (GABA) is the major inhibitory transmitter of the mammalian brain. ${ }^{1,2}$ GABA's actions are mediated by a ligand-gated ion channel, which is modulated by three major binding domains: the GABA-A receptor site, the "central" benzodiazepine receptor site, and the picrotoxin/barbiturate binding site. ${ }^{2,3}$ Working in concert, these sites modify cerebral excitability by altering the flux of chloride in CNS neurons. ${ }^{2,3}$

Over the years, it has been postulated that a number of the anticonvulsant drugs may suppress seizures by enhancing activity in the GABAergic systems of the brain. Evidence is strongest for the barbiturates ${ }^{4-6}$ and the benzodiazepines, ${ }^{4,7,8}$ but GABAergic interactions have also been suggested for phenytoin $^{9-11}$ carbamazepine $^{12}$ and valproate. ${ }^{13-16}$

Recent electrophysiological studies do not support the GABAergic hypotheses for phenytoin or carbamazepine, and valproate's interactions with GABA (if any) appear to be slow and indirect. ${ }^{17,18}$ The barbiturates and benzodiazepines, however, clearly do enhance GABA-mediated inhibition, and this is generally believed to constitute their mechanism of action. ${ }^{17,18}$

Even as applied to the benzodiazepines, however, the GABA hypothesis presents certain problems. The first problem is that the benzodiazepines and barbiturates - which are believed to share a common mechanism - have different effects on seizures.
At low doses, the benzodiazepines (e.g., clonazepam) are clinically effective against absence attacks, whereas the barbiturates (e.g., phenobarbital) are not. ${ }^{19}$ Conversely, at low doses, the barbiturates strongly antagonize convulsive seizures, whereas the benzodiazepines do not. ${ }^{19}$ Similar differences are observed in animal experiments. The benzodiazepines are far more potent against pentylenetetrazol threshold (MET) seizures, which model absence attacks, than against maximal electroshock (MES) seizures, which model tonic-clonic attacks. ${ }^{20}$ The barbiturates do not show this difference in potency. ${ }^{20}$ These differences in anticonvulsant effect are hard to explain if the barbiturates and the benzodiazepines share a common mechanism of action.

A second problem with the GABA hypothesis of benzodiazepine actions is that the low-dose effects of the benzodiazepines do not resemble those of the known GABA agonists. The benzodiazepines - as noted above - are highly effective

From the Department of Pharmacology (J.F., S.J.M., W.B.S., W.M.B.) and Bloorview Epilepsy Program (J.F., W.M.B.), University of Toronto, Toronto

RECEIVED JUNE 25, 1993. ACCEPTED IN FINAL FORM OCTOBER 27, 1993.

Reprint requests to: W. McIntyre Burnham, Ph.D., Department of Pharmacology, Medical Sciences Building, University of Toronto, Toronto, Ontario, Canada M5S IA8 
against absence attacks, whereas GABA-A receptor agonists, like progabide, are not. ${ }^{18}$ In animal models, the GABA agonists actually exacerbate absence-type seizures, whereas the benzodiazepines suppress them. ${ }^{18}$ It is hard to see why these differences should occur if the benzodiazepines act by enhancing GABA-A mediated chloride flux. It is important to note, however, that these problems only exist at low doses of benzodiazepines. At high doses, the benzodiazepines resemble the GABA-A agonists, showing activity against convulsive seizures in humans $^{21}$ and MES seizures in animals. ${ }^{20}$

The work of Carlen et al. ${ }^{22,23}$ offers a possible solution to the problems related to the GABA hypothesis of benzodiazepine actions. Carlen et al. found that at low concentrations - those clinically used to control anxiety and absence seizures - the benzodiazepines primarily act on calcium-activated potassium flux. Enhancement of GABAergic inhibition was also observed, but this occurred only at higher concentrations. These findings might explain why benzodiazepines act differently than GABA agonists at low doses, but similarly to GABA agonists at high doses. Unfortunately, not all of the electrophysiological reports agree with the data of Carlen et al. Macdonald and McLean ${ }^{17}$ have reported benzodiazepine enhancement of GABAergic inhibition within - or even below - the therapeutic concentration range for benzodiazepines.

Recently, a biochemical assay has been developed which directly measures GABA-stimulated chloride uptake. ${ }^{24,25}$ This assay allows a direct test of the effects of anticonvulsants on GABA-stimulated uptake and, in particular, of the effects of the barbiturates and benzodiazepines. Indirect effects - such as those postulated for valproate ${ }^{18}$ - cannot be detected, but all direct and immediate effects should be observed. When microsacs (unfiltered synaptoneurosomes) ${ }^{26}$ or synaptoneurosomes ${ }^{27.28}$ are used, both pre- and postsynaptic effects can be measured.

In the present study, the chloride uptake assay was used to investigate the effects of anticonvulsant drugs on GABA-A stimulated chloride uptake. In initial experiments, eight standard drugs - carbamazepine, clonazepam, diazepam, ethosuximide, phenobarbital, phenytoin, primidone, and valproate - were screened at "mid" and "high" free anticonvulsant concentrations. Two concentrations were used for screening, because the exact therapeutic range of some of the drugs is unclear (see below). In subsequent experiments, full concentration-response tests were done for clonazepam, diazepam and phenobarbital,

Table 1. Anticonvulsant Drugs: therapeutic ranges (free drug) and concentrations used for screening.

\begin{tabular}{lcc}
\hline Drugs & Therapeutic Range & Concentrations Used \\
\hline Phenytoin & $4.0-8.0 \mu \mathrm{M}$ & $6,8 \mu \mathrm{M}$ \\
Carbamazepine & $4.2-12.6 \mu \mathrm{M}$ & $5,13 \mu \mathrm{M}$ \\
Phenobarbital & $25.0-100.0 \mu \mathrm{M}$ & $60,100 \mu \mathrm{M}$ \\
Primidone & $18.4-44.0 \mu \mathrm{M}$ & $30,44 \mu \mathrm{M}$ \\
Ethosuximide & $300.0-700.0 \mu \mathrm{M}$ & $500,700 \mu \mathrm{M}$ \\
Valproate & $17.5-210.0 \mu \mathrm{M}$ & $115,210 \mu \mathrm{M}$ \\
Clonazepam & $3.2-12.8 \mathrm{nM}^{\mathrm{b}}$ & $10,30 \mathrm{nM}$ \\
Diazepam & $10.0-14.0 \mathrm{nM}^{\mathrm{c}}$ & $10,40 \mathrm{nM}^{\mathrm{c}}$ \\
\hline
\end{tabular}

a Free anticonvulsant concentrations are based on Macdonald and McLean. ${ }^{17}$

b Gilman et al..$^{37}$ give a broader range of $2.2-31 \mathrm{nM}$.

c Anxiolytic concentrations are based on Gilman et al. ${ }^{37}$ The free concentration achieved after intravenous injection is at least twice as high. ${ }^{21}$ For screening, one concentration in the anxiolytic range and one in the intravenous range were used. the three drugs which produced significant enhancement. A recent publication ${ }^{29}$ has suggested that diazepam significantly enhances chloride flux at concentrations within the therapeutic range. Our own data, presented below, suggest a different conclusion. Table 1 indicates "free" therapeutic (anticonvulsant) concentrations for the eight anticonvulsants used, plus the "mid" and "high" concentrations used in initial screening.

Chronic anticonvulsant blood levels for diazepam have not been clearly established, since the drug is primarily used for the intravenous treatment of status epilepticus. ${ }^{19}$ In our initial screens, therefore, one diazepam concentration in the anxiolytic range was tested, plus a second, higher concentration, similar to the concentrations reported after acute intravenous injections for status. $^{21}$

\section{Materials and MethodS}

\section{Materials}

${ }^{36} \mathrm{Cl}^{-}\left(8.86 \mathrm{mCi} / \mathrm{gm} \mathrm{Cl}^{-}\right)$was purchased from ICN (Irvine, CA). Picrotoxin (PTX), GABA and phenobarbital were purchased from Sigma Chemical Co. (St. Louis, MO). The remaining anticonvulsant drugs were obtained in pure substance form from their manufacturers. All other reagents were of the highest available grade.

Drug solutions were prepared fresh on the day of use. Stock solutions of phenobarbital, valproate and ethosuximide were mixed in assay buffer. Stock solutions of phenytoin were mixed in assay buffer plus $0.05 \mathrm{~N} \mathrm{NaOH}$. Stock solutions of diazepam, clonazepam, carbamazepine and primidone were prepared using dimethylsulfoxide (DMSO). Aliquots of stock solution were subsequently diluted in assay buffer to obtain the appropriate final assay concentrations. Trace $\mathrm{NaOH}$ in the final assay tubes did not measurably affect $\mathrm{pH}$. DMSO concentrations in the final assay tubes were less than $0.01 \%$.

\section{Preparation of Microsacs}

The microsac preparation is similar to the synaptoneurosome preparation, except that one filtration step is omitted. ${ }^{26}$ In the present experiment, microsacs were prepared using procedures previously described by Mihic et al. ${ }^{30}$ Briefly, male Sprague Dawley rats $(200-220 \mathrm{~g})$ were obtained from a breeder (Charles River, Canada) and housed in a vivarium $\left(22^{\circ} \mathrm{C}\right.$, lights on from 7:00 a.m. to 7:00 p.m. daily). On the day of assay, animals were sacrificed by decapitation and the brains were quickly removed and placed in ice-cold homogenization buffer (in mM: HEPES, 10; $\mathrm{NaCl}, 145 ; \mathrm{KCl}, 5 ; \mathrm{MgCl}_{2}, 1 ; \mathrm{CaCl}_{2}, 1 ;$ and glucose, 10 , adjusted to $\mathrm{pH} 7.4-7.5$ with Tris base). Cerebral cortices were isolated and gently hand-homogenized on ice $(8 \mathrm{ml}$ of buffer, 10 passes in a Potter-Elvehjem teflon-glass homogenizer). The homogenate was diluted to $30 \mathrm{ml}$ with buffer and then centrifuged at $1,000 \times \mathrm{g}$ for 15 minutes in a Sorvall $\mathrm{RC}-2 \mathrm{~B}$ centrifuge $\left(4^{\circ} \mathrm{C}\right)$. The supernatant was carefully decanted and the pellet resuspended in $8 \mathrm{ml}$ of buffer (manual homogenization 10 passes on ice), diluted to $30 \mathrm{ml}$, and centrifuged at $1,000 \times \mathrm{g}$ for 15 minutes. The final pellet was resuspended in $9.5 \mathrm{ml}$ of buffer (manual homogenization - 10 passes on ice), placed on ice, and used immediately in the uptake assays. Four separate preparations ( $=4$ separate brains) were used in all experiments, except the concentration-response diazepam experiment, which involved 6 separate preparations (6 separate brains). 


\section{Manual Assay of Chloride Influx}

The method of Mihic et al..$^{30,31}$ was used for chloride uptake assays. Briefly, $200 \mu \mathrm{l}$ aliquots of the ice-cold microsac preparation were placed in individual test tubes. Following a 4-min preincubation at $34^{\circ} \mathrm{C}$, chloride uptake was initiated by the addition of $100 \mu \mathrm{l}$ of buffer (also at $34^{\circ} \mathrm{C}$ ) containing ${ }^{36} \mathrm{Cl}^{-}(0.4 \mu \mathrm{Ci})$ \pm drugs (e.g., GABA, diazepam, phenobarbital, etc.) while the tube was being vortexed. The reaction was quenched after $3 \mathrm{sec}$ with $5 \mathrm{ml}$ of buffer containing $100 \mu \mathrm{M}$ picrotoxin. The contents of the test tube were then immediately filtered by suction through a pre-wetted Schleicher \& Schuell (S\&S) \#34 filter supported on a Hoeffer manifold (Hoeffer Scientific, San Francisco, $\mathrm{CA}$ ). The filter was washed three more times with $5 \mathrm{ml}$ of the PTX buffer, once with the manifold tower in place, and twice after its removal. Filters were placed in minivials and equilibrated for 24 hours in $4 \mathrm{ml}$ of Cytoscint (ICN) scintillation counting fluid. The vials were then counted for $20 \mathrm{~min}$ each in a Beckman LS-5801 scintillation counter. Protein concentration in microsac preparations was determined by the method of Lowry et al. ${ }^{32}$ Chloride uptake was expressed as nmoles chloride per $\mathrm{mg}$ of protein. The amount of ${ }^{36} \mathrm{Cl}^{-}$bound to filters in the absence of tissue $(40 \mathrm{cpm})$ was subtracted from all tissue sample values. In studies of GABA-stimulated uptake, a GABA concentration of $5 \mu \mathrm{M}$ GABA was used. This concentration has been found to increase basal uptake by about $50 \% .{ }^{30}$

\section{Statistics}

Data were analyzed using one-way analyses of variance (ANOVA), followed by Fisher's post-hoc tests for multiple comparisons.

\section{RESULTS}

Table 2 presents the results of initial experiments in which "mid" and "high" therapeutic concentrations of eight anticonvulsants were screened for their effects on GABA-stimulated chloride uptake. Basal uptake (uptake in the absence of GABA)

Table 2. Effects of anticonvulsant drugs on specific chloride uptake. ${ }^{a}$

\begin{tabular}{|c|c|c|c|}
\hline Drug & $5 \mu M$ GABA & $\begin{array}{l}\text { 5 } \mu M \text { GABA } \\
\text { +drug (mid dose) }\end{array}$ & 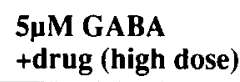 \\
\hline Phenytoin & $7.1 \pm 0.6$ & $7.4 \pm 0.4$ & $7.8 \pm 0.7$ \\
\hline Carbamazepine & $7.1 \pm 0.6$ & $7.8 \pm 0.3$ & $7.8 \pm 0.7$ \\
\hline Phenobarbital & $7.1 \pm 0.6$ & $13.5 \pm 0.9^{b}$ & $15.8 \pm 1.2^{\mathrm{b}}$ \\
\hline Primidone & $7.1 \pm 0.6$ & $7.8 \pm 0.7$ & $8.6 \pm 0.6$ \\
\hline Ethosuximide & $8.3 \pm 0.6$ & $9.5 \pm 0.9$ & $9.3 \pm 1.1$ \\
\hline Valproate & $8.3 \pm 0.6$ & $8.1 \pm 0.6$ & $8.8 \pm 0.7$ \\
\hline Clonazepam & $9.2 \pm 0.3$ & $9.6 \pm 0.4$ & $11.1 \pm 0.3^{b}$ \\
\hline Diazepam & $6.3 \pm 0.2$ & $6.1 \pm 0.4$ & $7.5 \pm 0.2^{\mathrm{b}}$ \\
\hline
\end{tabular}

a Values are $\mathrm{nmol} / \mathrm{mg}$ protein \pm S.E.M. from 4 separate experiments (4 separate brains). Specific uptake was obtained by subtracting basal from total uptake. Basal uptake ranged from $16-18 \mathrm{nmol} / \mathrm{mg}$ protein. "Mid" and "high" concentrations used for each drug are indicated in Table 1 .

b $\mathrm{p}<0.02$, as compared to $5 \mu \mathrm{M}$ GABA alone. ranged from 16-18 nmole chloride/mg protein. Basal uptake was not changed by high therapeutic concentrations of any drug. GABA-stimulated uptake (uptake in the presence of $5 \mu \mathrm{M}$ GABA) was approximately $50 \%$ higher than basal uptake. GABA-stimulated uptake was significantly enhanced by three drugs: phenobarbital, clonazepam and diazepam.

Figure 1 presents the data obtained in a subsequent concentration-response study of phenobarbital. Phenobarbital enhanced GABA-stimulated chloride uptake over a wide range of doses. Significant enhancement was first observed at a concentration of $20 \mu \mathrm{M}$. At concentrations above $80 \mu \mathrm{M}$, basal uptake began to be enhanced as well. This effect first became significant at 320 $\mu \mathrm{M}$. At $100 \mu \mathrm{M}$, the highest phenobarbital concentration employed clinically, total enhancement was approximately $50 \%$. Higher concentrations of phenobarbital produced further enhancement, up to a maximum of about $333 \%$ at $640 \mu \mathrm{M}$, the highest concentration tested.

Figure 2 presents data obtained in concentration-response studies of clonazepam and diazepam. Neither clonazepam nor diazepam produced any change in basal uptake. Significant clonazepam enhancement of GABA-stimulated chloride uptake was first observed at $30 \mathrm{nM}$. A maximum enhancement of $84 \%$ was observed at $1700 \mathrm{nM}$, the highest concentration tested. Fifty percent enhancement was achieved between 100-200 nM. Significant diazepam enhancement was first observed at $40 \mathrm{nM}$. A maximal enhancement of $87 \%$ was observed at $1280 \mathrm{nM}$ $(1.28 \mathrm{uM})$, the highest concentration tested. Fifty percent enhancement was reached between $100-200 \mathrm{nM}$.

\section{Discussion}

It has been suggested that a number of the anticonvulsant drugs - and in particular the barbiturates and benzodiazepines act by enhancing activity in the GABAergic systems of the brain. The present study was designed to determine whether these drugs would enhance GABA-stimulated chloride uptake in a microsac preparation, and also whether the enhancement occurred at the concentrations normally used to control seizures.

In initial screens with "mid" and "high" concentrations, only phenobarbital, clonazepam and diazepam produced a significant enhancement of GABA-stimulated chloride uptake. In agreement with recent electrophysiological studies, ${ }^{17.18}$ these data suggest that only the barbiturates and benzodiazepines have a direct and immediate effect on GABA-mediated chloride flux. While it is possible that other drugs (e.g., valproate) may produce indirect effects on the GABA system, they do not directly enhance activity at the level of either the pre- or post-synaptic $\mathrm{GABA}_{\mathrm{A}}$ receptor complex.

Subsequent concentration-response studies were designed to determine whether the concentrations of phenobarbital, clonazepam and diazepam which produce enhancement correspond to the concentrations which produce anticonvulsant effects. It was found that phenobarbital enhanced GABA-stimulated uptake over the whole range of concentrations used clinically to stop seizures (25-100 $\mu \mathrm{M}$ ). Above $80 \mu \mathrm{M}$, an enhancement of basal - as well as GABA stimulated - uptake was observed, and, at $100 \mu \mathrm{M}$ - the highest concentration used clinically - a sizable total enhancement of about $50 \%$ was observed. These data confirm past studies which have shown that phenobarbital enhances chloride uptake at high concentrations, ${ }^{33-35}$ and extend them by showing that enhancement occurs 


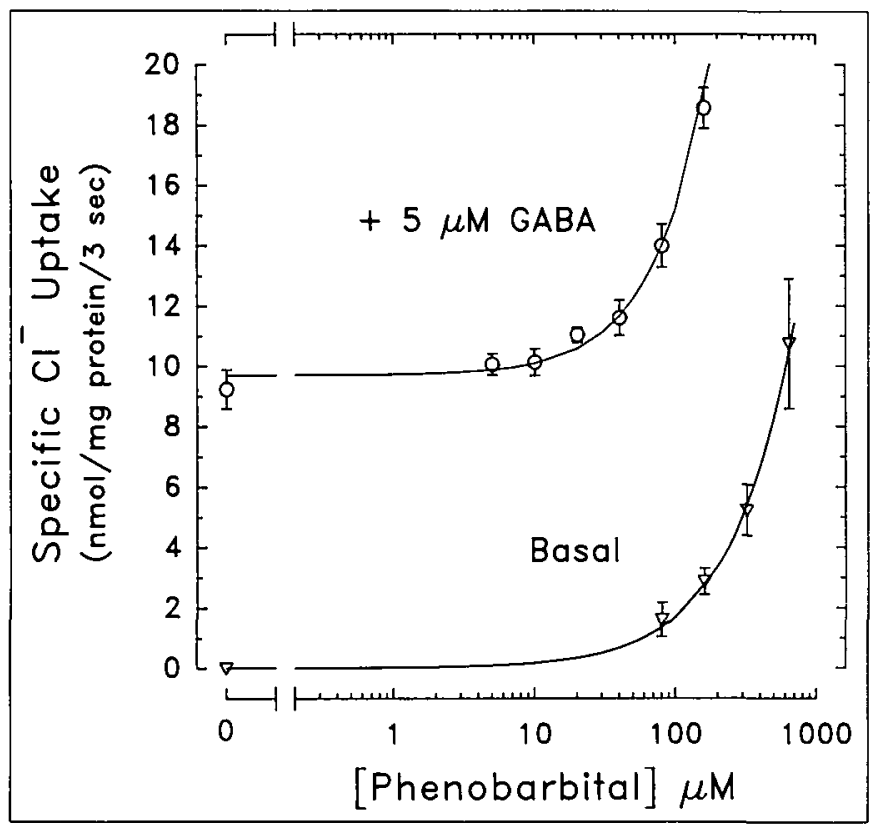

Figure 1: Effect of phenobarbital on basal ( $\nabla)$ and GABA-stimulated (O) $\mathrm{Cl}$ uptake in microsacs prepared from rat cerebral cortex. A 3-s manual incubation of microsacs with ${ }^{36} \mathrm{Cl}(0.4 \mu \mathrm{Ci})$ was used. Data are presented as "specific" uptake - with initial basal uptake subtracted and represent mean $\pm S E M$ (bars) values from 4 separate experiments $(=4$ separate brains $)$. Phenobarbital produced a significant enhancement of GABA-stimulated $\mathrm{Cl}$ uptake at all concentration $\geq 20 \mu \mathrm{M}(\mathrm{p}<$ 0.05 ). At $320 \mu M$, phenobarbital produced a mean uptake of $27.5 \pm 1.2$ nmoles/mg protein (192\% enhancement) and at $640 \mu \mathrm{M}$, phenobarbital produced a mean uptake of $39.9 \pm 1.4$ nmoles $/ \mathrm{mg}$ protein $(333 \%$ enhancement) (data not shown). Phenobarbital produced a significant enhancement of basal uptake at all concentrations $\geq 320 \mu M$.

throughout the full range of concentrations used clinically to control seizures. They are consistent with electrophysiological studies indicating that phenobarbital enhances GABA-mediated inhibition at concentrations between 25 and $100 \mu \mathrm{M},{ }^{17}$ and provide further support for the hypothesis that phenobarbital produces its anticonvulsant effects, at least in part, by enhancing GABAergic inhibition. ${ }^{17}$ The enhancement of basal uptake - which begins around $80 \mu \mathrm{M}$ and becomes increasingly significant at higher concentrations - may relate to the high-dose anesthetic actions of the barbiturates. ${ }^{36}$

In contrast, the enhancing effects of clonazepam and diazepam occurred at concentrations above those used for chronic therapy. Clonazepam produced little enhancement of chloride flux between 2 and $15 \mathrm{nM}$, the free concentrations commonly achieved after chronic oral anticonvulsant administration. ${ }^{17}$ At $30 \mathrm{nM}$, considered supra-therapeutic for seizure control by some authorities ${ }^{17}$ and high therapeutic by others, ${ }^{37}$ enhancement was only about $20 \%$. Fifty percent enhancement did not occur until a concentration of 100-200 nM, well above the concentrations achieved during chronic anticonvulsant therapy. Diazepam, likewise, produced little or no effect at 10-14 $\mathrm{nM}$, the free concentrations achieved during anxiolytic therapy. ${ }^{37}$ Significant effects were observed only at concentrations above $20 \mathrm{nM}$ - the concentrations achieved after rapid intravenous injection for status epilepticus. ${ }^{21}$ Fifty percent enhancement occurred at concentrations of $100-200 \mathrm{nM}$, roughly 10 times higher than those used to control anxiety. These findings are consistent with past studies showing that clonazepam and

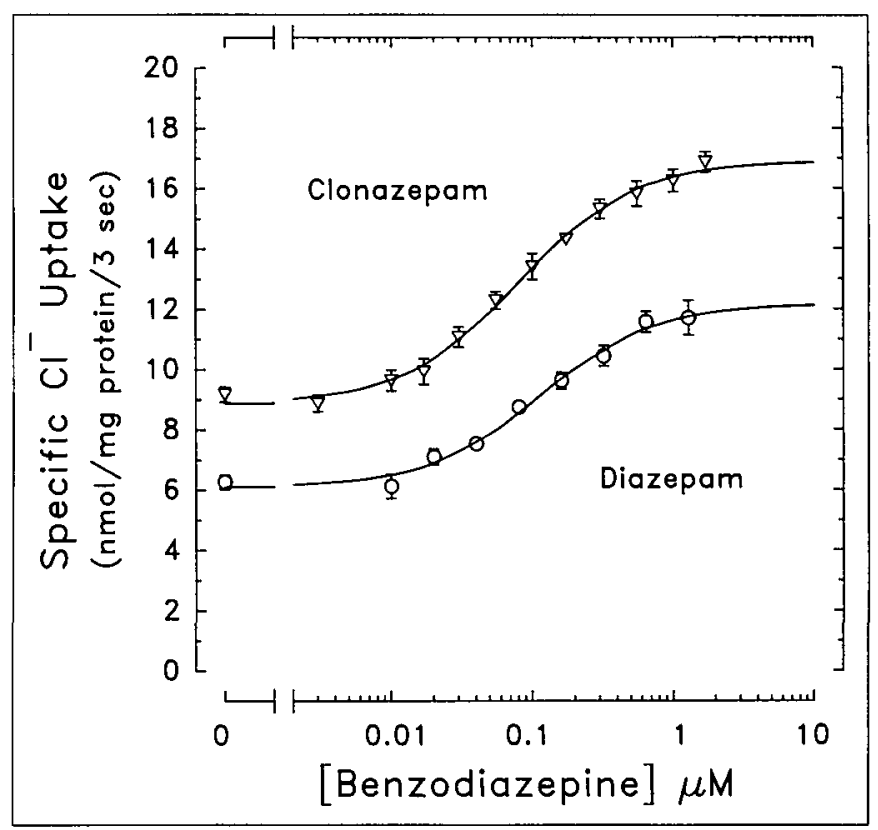

Figure 2: Effect of clonazepam ( $\nabla)$ and diazepam (O) on GABA-stimulated $\mathrm{Cl}^{-}$uptake in microsacs prepared from rat cerebral cortex. Data are presented as "specific" uptake - with initial basal uptake subtracted - and represent mean $\pm S E M$ (bars) values from 4 (clonazepam) or 6 (diazepam) separate experiments ( $=4$ or 6 separate brains). Clonazepam produced a significant enhancement of GABA-stimulated uptake at all concentrations $\geq 30 \mathrm{nM}$. Diazepam produced a significant enhancement of GABA-stimulated uptake at all concentrations $\geq 40 \mathrm{nM}$. Neither clonazepam nor diazepam produced a significant enhancement of basal uptake when tested at their highest doses (clonazepam: 1700 $n M$; diazepam: $(280 \mathrm{nM}$ ).

diazepam enhance chloride flux at high concentrations. ${ }^{38-40}$ They indicate, however, that there is no good correspondence between enhancement of GABA-stimulated chloride uptake as measured in microsacs and the benzodiazepine concentrations achieved in chronic anticonvulsant or anxiolytic therapy.

Other workers have sometimes reported that benzodiazepines enhance GABAergic function at clinically relevant concentrations. It has been suggested, for instance, that diazepam - at concentrations between 1-10 nM - enhances GABA-mediated chloride flux in cultured neurons derived from rodent spinal cord $^{41}$ and cortex. ${ }^{42}$ These reports are hard to evaluate, since the effect seems to occur below the therapeutic range. Other workers have reported that benzodiazepines enhance GABA binding at therapeutic (anxiolytic) concentrations. ${ }^{43}$ The order of potencies for this effect, however, does not correlate well with the clinical potencies of the benzodiazepines. ${ }^{43} \mathrm{~A}$ recent report suggesting that diazepam enhances chloride uptake with an $\mathrm{EC}_{50}$ of 12 $\mathrm{nM}^{29}$ is harder to explain. In our own hands, benzodiazepine enhancement does not occur at these concentrations.

Why should there be a mismatch between the benzodiazepine concentrations required to produce clinical effects and the concentrations required to produce in vitro effects on chloride uptake? Benzodiazepine actions are rapid and direct, and ought, therefore, to be observable in the present assay. In the clinical situation, diazepam's actions are enhanced by its active metabolite, nordiazepam, ${ }^{44}$ but this is not true of clonazepam, which lacks an active metabolite. ${ }^{19}$ It has been suggested that binding to only a very small proportion of benzodiazepine 
receptors may be required to produce a functional effect, ${ }^{18}$ but this is irrelevant in the present assay, where the functional effect was measured directly.

One possible explanation for the mismatch between clinical concentrations and in vitro effects is that the uptake assay is sub-sensitive to the actions of the benzodiazepines. Barbiturates in vitro potentiate GABA-stimulated chloride uptake at therapeutic concentrations, as does halothane (Mihic et al., unpublished data). It may be, however, that the uptake assay lacks some component necessary to duplicate the in vivo response to benzodiazepines. The internal environment of microsacs may not adequately model that found in neurons in vivo. For example, phosphorylation/dephosphorylation processes known to affect $\mathrm{GABA}_{\mathrm{A}}$ receptor function ${ }^{45}$ may not be functioning normally in microsacs.

Alternatively, as Carlen et al. ${ }^{22.23}$ have suggested, it may be that low-dose benzodiazepine effects are not mediated via the GABA system - that GABAergic effects come into play only at concentrations above those achieved in chronic benzodiazepine therapy. Although this hypothesis conflicts with much current theory, it would explain several paradoxes related to the lowdose actions of the benzodiazepines: 1) that low-dose benzodiazepines and barbiturates have a different spectrum of anticonvulsant effects, even though they are believed to have the same mechanism of action; 2) that low-dose benzodiazepine actions do not resemble the actions of the known GABA agonists; and 3) that benzodiazepines have different clinical actions at low and high doses. Further study of the mechanism of action of the benzodiazepines is clearly in order.

\section{ACKNOWLEDGEMENTS}

These experiments were supported by Grant MA 5611 from the Medical Research Council of Canada. J. Francis was supported by a fellowship from the Bloorview Epilepsy Program. W.B. Sneddon was supported by a fellowship from the Natural Science and Engineering Research Council of Canada. The authors would like to thank Drs. S.J. Kish and $\mathrm{H}$. Kalant for advice and assistance, and the following pharmaceutical companies for donations of drugs in pure substance form: Abbott (valproate); Ayerst (primidone); Parke-Davis (phenytoin, ethosuximide); Geigy Pharmaceuticals (carbamazepine); Hoffman-LaRoche (clonazepam, diazepam). S.J. Mihic's current address is: Department of Pharmacology, University of Colorado Health Sciences Centre, 4200 East Ninth Avenue, Denver, CO 80262

\section{REFERENCES}

1. Iversen LL and Bloom FE. Studies of the uptake of ${ }^{3} \mathrm{H}-\mathrm{GABA}$ and ${ }^{3} \mathrm{H}$-glycine in slices and homogenates of rat brain and spinal cord by electron microscopic autoradiography, Brain Res 1972; 41: $131-143$

2. Stephenson FA. Understanding the GABA-A receptor: a chemically gated ion channel. J Biochem 1988; $249: 21-32$.

3. Olsen RW. GABA benzodiazepine barbiturate receptor interactions. J Neurochem 1981; 37: 1-13.

4. Barker JL and McBurney RW. Phenobarbitone modulation of postsynaptic GABA receptor function on cultured mammalian neurons. Proc $R$ Soc Lond 1979; 206: 319-327.

5. Study RE and Barker JL. Diazepam and (-)-pentobarbital: fluctuation analysis reveals different mechanisms for potentiation of GABA responses in cultured central neurons. Proc Nat Acad Sci USA 1981; 78: 7180-7184.

6. Schwartz RD, Skolnick P, Seale TW and Paul SM. Demonstration of GABA/barbiturate receptor-mediated chloride transport in rat brain synaptoneurosomes: a functional assay of receptor-effector coupling. In: G. Biggio and E. Costa, eds. Advances in Biochemical Pharmacology. New York: Raven Press 1986; 33-49.
7. Tunnicliff G, Smith, JA and Ngo TT. Competition for diazepam receptor binding by diphenylhydantoin and its enhancement by gamma-aminobutyric acid. Biochem Biophys Res Commun 1979; $91:$ 1018-1024.

8. Tallman JF and Gallagher DW. The GABAergic system: a locus of benzodiazepine action. Ann Rev Neurosci 1985; 8: $21-44$.

9. Ayala GF, Lin S and Johnston D. The mechanism of action of diphenylhydantoin on invertebrate neurons. I. Effects on basic membrane properties. Brain Res 1977; 121: 245-258.

10. Aickin CC, Deisz RA and Lux HD. On the action of the anticonvulsant 5,5- diphenylhydantoin and the convulsant picrotoxin in crayfish stretch receptor. J Physiol 1981; 315: 157-173.

11. Spero L. Neurotransmitters and CNS disease. Epilepsy. Lancet 1982; 2: 1319-1322.

12. Skerritt JH, Johnston GA and Chen Chow S. Interactions of carbamazepine with benzodiazepine receptors. J Pharm Pharmacol 1983; 35: 464-465.

13. Macdonald RL and Bergey GK. Valproic acid augments GABAmediated postsynaptic inhibition in cultured mammalian neurons. Brain Res 1979; 170: 558-562.

14. Baldino F and Geller HM. Sodium valproate enhancement of inhibition: electrophysiological evidence for anticonvulsant activity. J Pharm Exp Ther 1981; 217: 445-450.

15. Loscher W. Effect of inhibitors of GABA aminotransferase on the metabolism of GABA in brain tissue and synaptosomal fractions. J Neurochem 1981; 36: 1521-1527.

16. Rock DM, McLean MJ and Macdonald RL. Sodium valproate selectively limits sustained high frequency repetitive firing of cultured mouse neurons. Soc Neurosci Abst 1984; 10: 872 .

17. Macdonald RL and McLean MJ. Anticonvulsant drugs: mechanisms of action. Adv Neurol 1986; 44: 713-736.

18. Rogawski MA and Porter RJ. Antiepileptic drugs: pharmacological mechanisms and clinical efficacy with consideration of promising developmental stage compounds. Pharm Rev 1990; 42: 223 286.

19. Rall TW and Schleifer LS. Drugs effective in the therapy of the epilepsies. In: A.G. Gilman, L.S. Goodman, T.W. Rall and F. Murad, eds. The Pharmacological Basis of Therapeutics. New York: MacMillan Publishing Company 1985; 446-472.

20. Krall RL, Penry JK, White BG, Kupferberg HJ and Swinyard EA. Antiepileptic drug development II: anticonvulsant drug screening. Epilepsia 1978; 19: 409-428.

21. Booker HE and Celesia GG. Serum concentrations of diazepam in subjects with epilepsy. Arch Neurol 1973; 29: 191-194.

22. Carlen PL, Gurevich N, Davies MF, Blaxter TJ and O'Beime MO. Enhanced neuronal $\mathrm{K}^{+}$conductance: a possible common mechanism for sedative-hypnotic drug action. Can J Physiol Pharmacol 1985; 63: 831-837.

23. Carlen PL, Gurevich N and Polc P. Low-dose benzodiazepine neuronal inhibition: enhanced $\mathrm{Ca}^{2+}$-mediated $\mathrm{K}^{+}$-conductance. Brain Res 1983; $271: 358-364$.

24. Harris RA and Allan AM. Functional coupling of gamma-aminobutyric acid receptors to chloride channels in brain membranes. Science 1985; 228: 1 108-1109.

25. Schwartz RD, Jackson JA, Weigert D, Skolnick P and Paul SM. Characterization of barbiturate-stimulated chloride efflux from rat brain synaptoneurosomes. J Neurosci 1985; 5: 2963-2970.

26. Daly JW, McNeal E, Partington C, Newirth $M$ and Creveling, $C R$. Accumulations of cyclic AMP in adenine-labelled cell-free preparations from guinea-pig cerebral cortex: role of alphaadrenergic and H1-histaminergic receptors. J Neurochem 1980; 35: 326-337.

27. Hollingsworth EB, Creveling CR, McNeal ET and Daly JW. A filtered neurosome enriched preparation from brain: morphology, receptors, enzymes, and cyclic AMP responses. Fed Proc 1984; 43: 1093.

28. Hollingsworth EB, McNeal ET, Burton JL, Williams RJ, Daly JW and Creveling CR. Biochemical characterization of a filtered synaptoneurosome preparation from guinea pig cerebral cortex: cyclic adenosine $3^{\prime}: 5^{\prime}$-monophosphate-generating systems, receptors, and enzymes. J Neurosci 1985; $5: 2240-2253$.

29. Facklam M, Schoch P and Haefely WE. Relationship between benzodiazepine receptor occupancy and potentiation of $\gamma$-aminobutyric acid-stimulated chloride flux in vitro of four ligands of 
differing intrinsic efficacies. J Pharmacol Exp Ther 1992; 261 : $1106-1112$

30. Mihic SJ, Kalant H, Liu JF and Wu PH. $\gamma$-Aminobutyric acid receptor/chloride channel complex in tolerance to ethanol and crosstolerance to diazepam and pentobarbital. J Pharmacol Exp Ther 1992; 261: 108.113.

31. Mihic SJ, Wu PH and Kalant H. Potentiation of $\gamma$-aminobutyric acid-mediated chloride flux by pentobarbital and diazepam but not ethanol. J Neurochem 1992; 58: 745-751.

32. Lowry $\mathrm{OH}$, Rosebrough NJ, Farr AL and Randall RJ. Protein measurement with the Folin phenol reagent. J Biol Chem 1951; 193: 161-175.

33. Schwartz RD, Skolnick P, Hollingsworth EB and Paul SM. Barbiturate and picrotoxin-sensitive chloride efflux in rat cerebral cortical synaptoneurosomes. FEBS Lett 1984; 175: 193-196.

34. Allan AM, Gallaher EJ, Gionet SE and Harris RA. Genetic selection for benzodiazepine ataxia produces functional changes in the $\gamma$-aminobutyric acid receptor chloride channel complex. Brain Res 1988; 452: 118-126.

35. Yakushiji T, Oyama Y and Akaike N. Comparative study on barbiturates using single isolated neurons: GABA-mimetic action and augmentatory action on GABA response. Brain Res 1989; 488: $357-360$.

36. Macdonald RL and McLean MJ. Cellular bases of barbiturate and phenytoin anticonvulsant drug action. Epilepsia 1982; 23 (Suppl. 1): S7-S18.

37. Gilman AG, Goodman LS, Rall TW and Murad F, eds. The Pharmacological Basis of Therapeutics, 7 th edn., New York: Macmillan Publishing Company 1985; 1680-1683.
38. Obata $T$ and Yamamura HI. The effect of benzodiazepines and beta-carbolines on GABA-stimulated chloride influx by membrane vesicles from the rat cerebral cortes. Biochem Biophys Res Commun 1986; 141: 1-6.

39. Morrow AL and Paul SM. Benzodiazepine enhancement of $\gamma$ aminobutyric acid-mediated chloride influx in rat brain synaptoneurosomes. J Neurochem 1988; 50: 302-306.

40. Mehta $A K$ and Ticku MK. Benzodiazepine and beta-carboline interactions with $\mathrm{GABA}$ receptor-gated chloride channels in mammalian cultured spinal cord neurons. J Pharmacol Exp Ther 1989; 249: 418-423.

41. Skerritt JH and Macdonald RL. Benzodiazepine receptor ligand actions on GABA responses: benzodiazepines, CL 218872 , Zopiclone. Eur J Pharmacol 1984; 101: 127-134.

42. White WF, Dichter MA and Snodgrass SR. Benzodiazepine binding and interactions with the GABA receptor complex in living cultures of rat cerebral cortex. Brain Res 1981; 215: 162-176.

43. Skerritt JH and Johnston GAR. Enhancement of GABA binding by benzodiazepines and related anxiolytics. Eur J Pharmacol 1983; 89: 193-198.

44. Baldessarini RJ. Drugs and the treatment of psychiatric disorders. In: Gilman AG, Goodman LS, Rall TW and Murad F, eds. The Pharmacological Basis of Therapeutics. New York: Macmillan Publishing Company $1985 ; 387-445$.

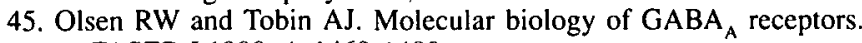
FASEB J 1990; 4: 1469-1480. 